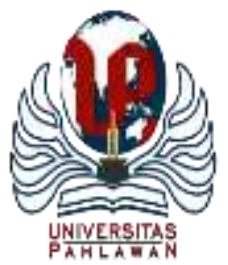

Edukatif : Jurnal Ilmu Pendidikan Volume 3 Nomor 6 Tahun 2021 Halm 4223 - 4233

EDUKATIF: JURNAL ILMU PENDIDIKAN

Research \& Learning in Education

https://edukatif.org/index.php/edukatif/index

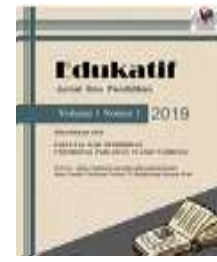

\title{
Pengembangan Pembelajaran Daring Materi Bangun Ruang Sederhana menggunakan Metode Pembelajaran Berbasis Proyek dengan Kearifan Lokal Kota Tomohon
}

\author{
Yeremia Gabriel Langi ${ }^{1}$, Jamalri Payow ${ }^{2}$, Gideon Christian ${ }^{3}$, Realita Meydena Andhela Totoda ${ }^{4}$, Juliana \\ Margareta Sumilat ${ }^{5 凶}$ \\ PGSD, Universitas Negeri Manado, Indonesia ${ }^{1,2,4,5}$ \\ PTIK Universitas Negeri Manado, Indonesia ${ }^{3}$ \\ E-mail : yeremiagabriellangi@gmail.com ${ }^{1}$, jamalripayow3@gmail.com² ${ }^{2}$, refih26@gmail.com ${ }^{3}$, \\ realitaadhellatotoda@gmail.com ${ }^{4}$,julianasumilat@unima.ac.id
}

\begin{abstract}
Abstrak
Tujuan penelitian ini adalah mengembangan pembelajaran daring materi bangun ruang sederhana menggunakan metode pembelajaran berbasis proyek dengan kearifan lokal kota tomohon, Jenis penelitian yang digunakan adalah penelitian pengembangan dengan langkah Define, Design, Development. Penelitian ini dilaksanakan di prodi PGSD dan subjek uji cobanya pada 6 peserta didik kelas V SD Negeri 2 Tomohon. Hasil uji ahli melalui angket, dan nilai hasil belajar diperoleh dari lembar kerja siswa dan tes hasil belajar. Penilaian ranah psikomotor melalui video pembuatan proyek taman mini berbentuk bangun ruang sederhana. Penilaian afektif diperoleh melalui observasi pada aktivitas peserta didik dalam pembelajaran baik synchronous dan asynchronous. Berdasarkan hasil uji ahli media dan bahasa diperoleh rata-rata 87,70, dan hasil uji ahli materi diperoleh rata-rata 83,68 dengan kritia layak. Hasil penilaian ranah kognitif menunjukan bahwa 5 peserta didik mengalami ketuntasan dan penilaian psikomotor menunjukan 5 peserta didik mengalami ketuntasan. Hasil penilaian afektif pada setiap aspek tanggung jawab, disiplin dan percaya diri menunjukan kemampuan minimal "cukup". Dengan demikian dapat disimpulkan bahwa produk pengembangan pembelajaran yang dilakukan oleh peneliti layak untuk digunakan.
\end{abstract}

Kata Kunci: penelitian pengembangan, pembelajaran daring, bangun ruang.

\begin{abstract}
The aims of this research is to develop online learning of Solid Figure using project-based learning methods with local wisdom the city of Tomohon. This research used is development research method. This research was conducted in the elementary teacher education program and the test subjects were 6 of fifth grade students of SD Negeri 2 Tomohon. The results of development are tested by experts through a questionnaire. The value of learning outcomes is obtained from student worksheets and learning outcomes tests. Assessment of the psychomotor domain through video assessments of making a mini garden project in the form of a Solid Figure. Affective assessment is obtained through observation of student activities in both synchronous and asynchronous learning. Based on the results of the media and language expert test, an average of 87.70, and the material expert test obtained an average of 83.68, with proper criteria. The results of the cognitive assessment showed that 5 students experienced completeness and psychomotor assessment 5 students experienced completeness. The results of the affective assessment on every aspect of responsibility, discipline and selfconfidence show a minimum ability of "sufficient". Thus, it can be concluded that the product of learning development is feasible to use.
\end{abstract}

Keywords: development, online learning, solid figure.

Copyright (c) 2021 Yeremia Gabriel Langi, Jamalri Payow, Gideon Christian, Realita Meydena Andhela Totoda, Juliana Margareta Sumilat

$\triangle$ Corresponding author

Email : julianasumilat@unima.ac.id

DOI : https://doi.org/10.31004/edukatif.v3i6.1412

ISSN 2656-8063 (Media Cetak)

ISSN 2656-8071 (Media Online)

Edukatif : Jurnal Ilmu Pendidikan Vol 3 No 6 Tahun 2021 p-ISSN 2656-8063 e-ISSN 2656-8071 
4224 Pengembangan Pembelajaran Daring Materi Bangun Ruang Sederhana menggunakan Metode Pembelajaran Berbasis Proyek dengan Kearifan Lokal Kota Tomohon - Yeremia Gabriel Langi, Jamalri Payow, Gideon Christian, Realita Meydena Andhela Totoda, Juliana Margareta Sumilat

DOI: https://doi.org/10.31004/edukatif.v3i6.1412

\section{PENDAHULUAN}

Covid-19 telah menyebar ke berbagai negara di dunia, termasuk Indonesia. Penyebaran penyakit ini di Sulawesi utara dimulai pada tanggal 16 maret 2020. Covid-19 memiliki karakteristik penyebaran yang cukup cepat (Prastyowati, 2020). Hal ini menyebabkan pemerintah mengambil kebijakan untuk menjalankan pembelajaran daring, agar semua peserta didik masih tetap bisa belajar walaupun hanya dari rumah. Pada tataran pelaksanaannya pembelajaran daring memerlukan dukungan perangkat-perangkat seperti smarphone, laptop, dan komputer yang dapat dipergunakan untuk mengakses informasi kapan saja dan dimana saja (Sadikin \& Hamidah, 2020).

Hasil wawancara dengan kepala sekolah SD Negeri 2 Tomohon juga menyatakan bahwa pembelajaran daring dapat terlaksana karena kemajuan teknologi yang begitu pesat, namun karena kemampuan guru masih terbatas dan wabah ini terkesan begitu mendadak, maka para guru di SD Negeri 2 Tomohon hanya menggelar pembelajaran daring dengan mengirim tugas lewat chatting wa, sehingga orang tua harus berperan ekstra dalam mendampingi anak. Oleh karena itu diperlukan pengembangan pembelajaran daring, dengan menggunakan metode-metode pembelajaran yang tepat serta kearifan lokal yang ada di kota Tomohon untuk bisa memaksimalkan hasil belajar peserta didik.

Pengembangan pembelajaran daring harus menggunakan metode pembelajaran yang mampu memberikan ruang bagi proses evalausi perkembangan peserta didik melalui prosesnya. Metode pembelajaran berbasis proyek merupakan satu metode pembelajaran yang baik dan menggunakan proyek sebagai inti pembelajaran (Holis, 2020). Pembelajaran ini merupakan metode pembelajaran inovatif yang melibatkan kerja proyek dimana peserta didik bekerja secara mandiri dalam mengkonstruksi pembelajarannya dan memberikan hasil belajar yang optimal (Sa'adah, 2018), Seperti hasil penelitian dari (Elvi, 2018) yang menyatakan bahwa pelaksanaan pembelajaran matematika dengan metode pembelajaran berbasis proyek di Kelas V SD Negeri 130 Rantonatas, mengalami peningkatan yang sangat baik dari guru maupun peserta didik sehingga 2 meningkatkan motivasi dan hasil belajar peserta didik bahkan meningkatkan cara berpikir kreatif peserta didik. (Nadziroh, 2017) juga menemukan bahwa pembelajaran daring efektif meningkatkan mutu pembelajaran, karena proses pembelajaran tidak hanya terpaku pada waktu dan ruang saja. Pengembangan pembelajaran daring metode pembelajaran berbasis proyek juga dapat memanfaatkan kearifan lokal daerah yang ada di kota Tomohon yaitu budaya masyarakat yang senang menanam berbagai jenis bunga sehingga Kota Tomohon dikenal dengan Kota Bunga. Pada setiap tahunnya diselenggarakan Tomohon Flower Festival (TIFF), yang bertujuan untuk mempromosikan potensi Kota Tomohon sebagai Kota Bunga agar dapat menjadi pusat industri bunga di Indonesia Timur (Kowaas, 2017). Dalam merespons setiap tantangan yang muncul dalam pembelajaran daring, materi bangun ruang sederhana diharapkan mampu memberikan motivasi serta kreatifitas belajar bagi peserta didik dalam pembelajaran secara daring. Dan untuk pengembangan pembelajaran daring materi bangun ruang sederhana dengan kearifan lokal Kota Tomohon dapat dilakukan dengan cara membuat pot bunga yang berbentuk balok, tabung, kerucut, bola, prisma tegak segitiga, dan limas segitiga yang bisa digunakan oleh guru sebagai alat atau bahan ajar untuk peserta didik.

Berdasarkan uraian tersebut, peneliti melakukan penelitian dengan judul: Pengembangan Pembelajaran Daring Materi Bangun Ruang Sederhana Menggunakan Metode Pembelajaran Berbasis Proyek dengan Kearifan Lokal Kota Tomohon. Banyak penelitan yang dilakukan tentang pembelajaran daring, namun kebanyakan penelitian yang dilakukan sebatas pada pembuatan media (Mahadiraja \& Syamsuarnis, 2020) dan keefektifan (Ameli, 2020), sementara penelitian ini mengembangkan pembelajaran daring yang dibangun mulai dari pembuatan media pembelajaran, media evaluasi hasil belajar, dan media proses pembelajaran. 
4225 Pengembangan Pembelajaran Daring Materi Bangun Ruang Sederhana menggunakan Metode Pembelajaran Berbasis Proyek dengan Kearifan Lokal Kota Tomohon - Yeremia Gabriel Langi, Jamalri Payow, Gideon Christian, Realita Meydena Andhela Totoda, Juliana Margareta Sumilat

DOI: https://doi.org/10.31004/edukatif.v3i6.1412

\section{METODE PENELITIAN}

Penelitian Pengembangan Pembelajaran Daring Materi Bangun Ruang Sederhana ini dilakukan di SD Negeri 2 Tomohon, pada semester ganjil tahun ajaran 2021/2022. Pada penelitian ini, peneliti menggunakan model 4D yang di kembangkan oleh Thiagarajan, dkk pada tahun 1974 (Fredyanan, 2016). 4D merupakan singkatan dari design, define, development dan Dissemination. Namun pada penelitian ini hanya dilakukan sampai pada 3D saja yaitu; design, define dan develoment, untuk bagian dissemination tidak dilaksanakan karena adanya keterbatan waktu. Pada tahap define, peneliti menghubungi kepala sekolah untuk izin pelaksanaan penelitian pada kelompok kecil peserta didik kelas V SD Negeri 2 Tomohon, kemuadian membahas aktivitas atau kegiatan penelitian yang akan dilakukan oleh peneliti dengan peserta didik kepada wali kelas sekaligus menganalisis kurikulum serta karakteristik peserta didik untuk mengetahui kemampuan akademik individu, karakteristik fisik, kemampuan kerja kelompok, motivasi belajar, latar belakang ekonomi, sosial, dan pengalaman belajar sebelumnya dari setiap peserta didik yang ada di kelas V SD Negeri 2 Tomohon Berdasarkan hasil analisis tersebut peneliti menentukan tujuan pembelajaran, dan melakukan studi literatur untuk mencari tau cara menggunakan beberapa aplikasi yang akan digunakan untuk mengedit foto, video dan buku. Kemudian peneliti mengkaji masalah-masalah yang ada dan yang mungkin akan dihadapi disekolah serta solusi apa yang akan peneliti gunakan untuk mengatasi masalah-masalah tersebut.

Pada tahap kedua dalam penelitian ini, peneliti melakukan kegiatan design atau perancangan pada pengembangan pembelajaran daring materi bangun ruang sederhana dengan menggunakan metode pembelajaran berbasis proyek yang akan dihubungkan dengan kearifan lokal yang ada di kota tomohon kegiatan design atau perancangan yang dilakukan oleh peneliti berupa; design RPP, Story board media pembelajaran berupa dua buah video, bahan ajar berupa buku guru (E-Book), kisi-kisi evaluasi proses belajar (LKPD), kisi-kisi evaluasi hasil belajar (lembar tes hasil belajar) beserta dengan kunci jawaban. Teknik pengumpulan data uji ahli menggunakan angket berupa google formulir ahli untuk menguji validitas dari produk hasil pengembangan pembelajaran yang sudah dikembangkan oleh peneliti. Selanjutnya data hasil belajar pada aspek kognitif diperoleh melalui LKPD untuk penilaian proses, dan tes tertulis pada penilaian hasil belajar. Data hasil belajar pada aspek psikomotor diperoleh melalui lembar observasi pada video penjelasan pembuatan proyek taman mini. Data hasil belajar pada aspek afektif diperoleh melalui lembar observasi pada aktifitas selama proses pembelajaran. Analisis data hasil belajar ranah kognitif peserta didik diperoleh dari rumus berikut:

$$
\text { Total nilai }=60 \% \text { LKPD }+40 \% \text { Tes tertulis }
$$

Hasil belajar ranah psikomotor diolah dengan rumus sebagai berikut.

$$
\text { Total nilai }=\frac{\text { Total Scor }}{\text { Skor Maksimal }} \times 100
$$

Hasil belajar ranah afektif : Kurang $=1$, Cukup $=2$, Baik $=3$, Sangat Baik $=4$.

\section{HASIL PENELITIAN DAN PEMBAHASAN}

Pada penelitian pengembangan ini, peneliti mengembangan beberapa bagian perangkat yaitu; 1) buku siswa (LKPD), 2) bahan ajar/ Buku Guru, 3) Media pembelajaran video, 4) evaluasi hasil belajar (e-tes), 5) layout google classroom. LKPD disusun berdasarkan hasil analisis kurikulum serta analisis karakteristik peserta didik di SD Negeri 2 Tomohon, khususnya peserta didik yang ada di kelas V. Pada LKPD yang dikembangkan, terdapat aktivitas atau kegiatan yang dilakukan oleh peserta didik baik dalam kegiatan pembelajaran maunpun kegiatan pembuatan proyek. Tampilan depan atau cover dari buku peserta didik (LKPD) dapat dilihat pada gambar berikut. 
4226 Pengembangan Pembelajaran Daring Materi Bangun Ruang Sederhana menggunakan Metode Pembelajaran Berbasis Proyek dengan Kearifan Lokal Kota Tomohon - Yeremia Gabriel Langi, Jamalri Payow, Gideon Christian, Realita Meydena Andhela Totoda, Juliana Margareta Sumilat

DOI: https://doi.org/10.31004/edukatif.v3i6.1412

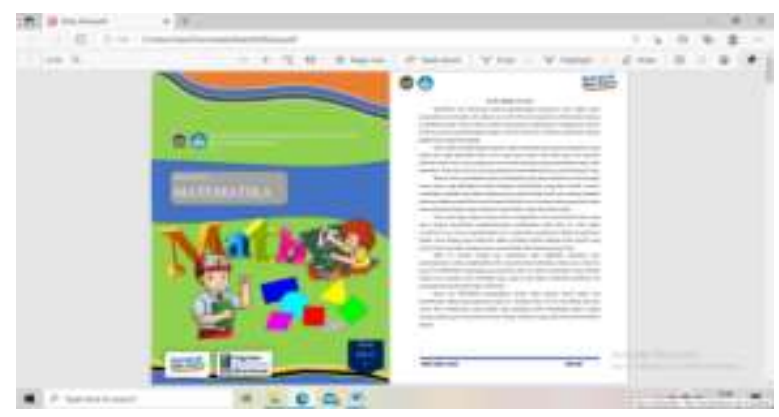

Gambar 1. Tampilan Depan Siswa (LKPD)

Pada kegiatan 2) peneliti melakukan penyusunan buku guru (E-Book). Penyusunan buku guru dimaksudkan untuk memberikan gambaran materi kepada peserta didik dan teknik pembelajaran yang dilalui untuk membuat peserta didik mencapai tujuan pembelajaran. buku guru ini juga mempermudah kegiatan belajar mengajar. Guru dan peserta didik tidak lagi perlu saling kirim mengirim tugas ataupun materi melalui WhatsApp karena materi atau buku guru sudah ada di google classroom.

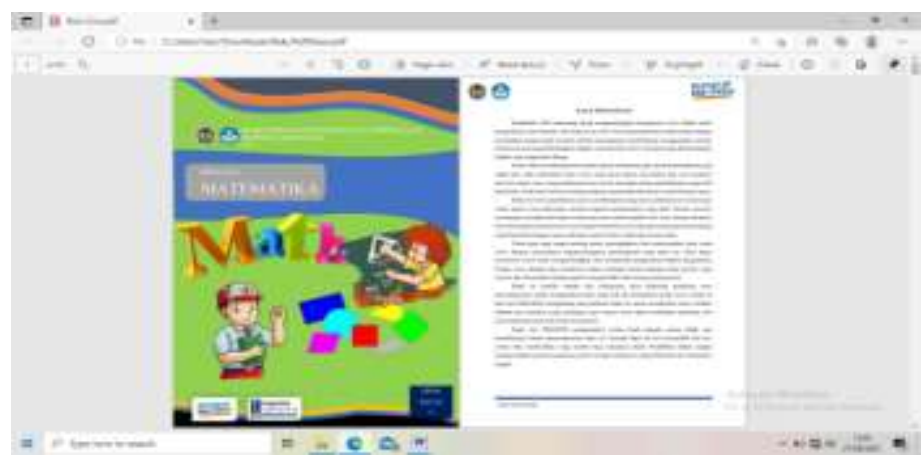

Gambar 2. Tampilan Depan Buku Guru (E-Book)

Pada kegitan 3) Peneliti melakukan pembuatan media Pembelajaran berupa video materi bangun ruang sederhana dan video pembuatan proyek taman mini, berdasarkan dari story board yang sudah di rancang sebelumnya. Video dibuat oleh peneliti untuk memudahkan guru dalam melakukan kegiatan pembelajaran khususnya pada saat menjelaskan materi atau langkah-langkah kerja proyek kepada peserta didik dan juga mempermudah peserta didik dalam kegiatan pembelajaran daring karena peserta didik tidak perlu takut ketinggalan materi ataupun penjelasan dari guru lagi, hanya perlu menonton video yang suddah dibuat oleh guru tersebut. Tampilan dari kedua video tersebut dapat dilihat pada gambar berikut.
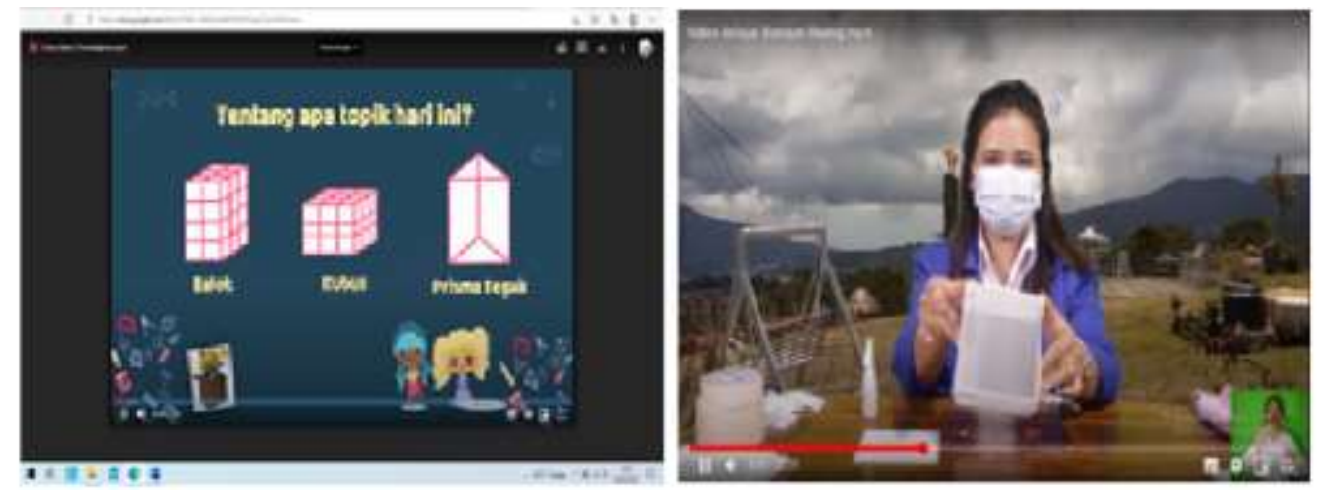

Gambar 3. Tampilan Video Penjelasan Materi dan Video Penjelasan Langkah-Langkah Pembuatan Proyek 
4227 Pengembangan Pembelajaran Daring Materi Bangun Ruang Sederhana menggunakan Metode Pembelajaran Berbasis Proyek dengan Kearifan Lokal Kota Tomohon - Yeremia Gabriel Langi, Jamalri Payow, Gideon Christian, Realita Meydena Andhela Totoda, Juliana Margareta Sumilat

DOI: https://doi.org/10.31004/edukatif.v3i6.1412

Pada kegiatan 4) Peneliti membuat e-tes yang berisi 3 buah soal tentang materi bangun ruang sederhana. e-tes dibuat dalam bentuk google formulir yang dibagikan kepada peserta didik melalui google classroom yang bisa diakses oleh semua peserta didik. e-tes Hasil Belajar dibuat sebagai media untuk peneliti bisa memperoleh data dari hasil evaluasi akhir kegiatan pembelajaran peserta didik. Tampilan e-tes Hasil Belajar dapat dilihat pada gambar berikut.

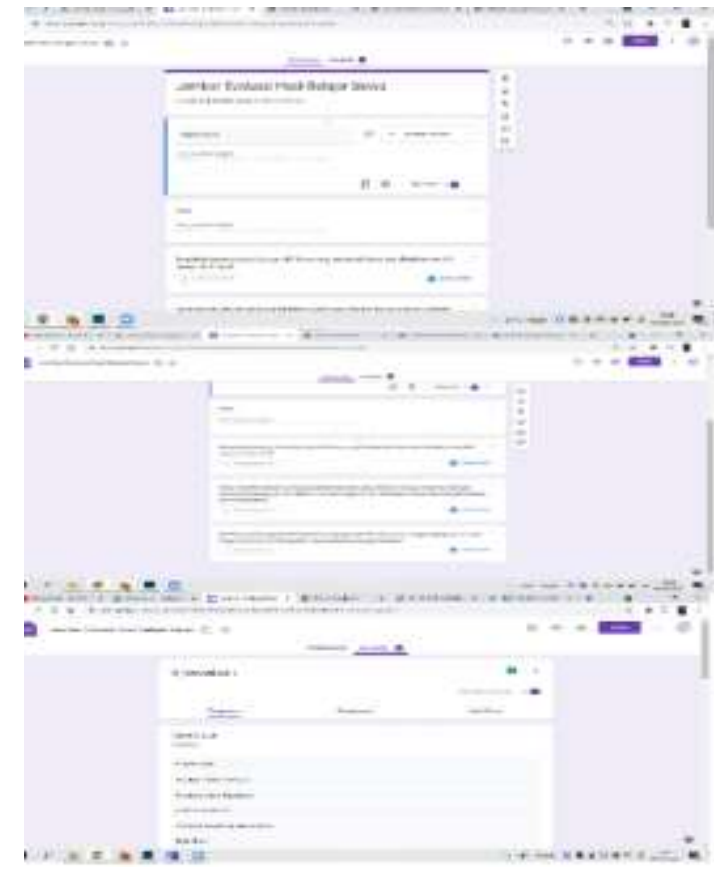

Gambar 4. Tampilan e-tes Hasil Belajar

Untuk mengetahui kevaliditasan dari semua produk pembelajaran yang sudah dikembangkan, peneliti melakukan uji validasi oleh pakar ahli yaitu ahli materi, ahli media dan ahli bahasa. Validasi ahli materi diperlukan sebagai suatu bentuk evaluasi dari bahan ajar atau materi, serta penyajian dari produk yang dikembangkan. Ahli materi mengatakan bahwa secara keseluruhan produk pengembangan pembelajaran daring yang dihasilkan sudah baik dan layak untuk digunakan, dan ahli materi juga memberikan saran perbaikan yaitu pada bahan ajar yang berisi materi bangun ruang sederhana perlu ditambahkan pada materi mengenai titik sudut pada materi kubus, balok, dan prisma segitiga. Kemudian di susun lagi secara rurut mulai dari titik sudut, rusuk, bidang, diangonal bidang, diagonal ruang, luas permukaan dan volume bangun ruang. berwarna dan perlu ekspresif lagi dalam kegiatan pembelajaran agar peserta didik bisa lebih antusias ketika mengikuti kegiatan pembelajaran. Validasi Hasil uji ahli media dan bahasa juga menyatakan bahwa, secara keseluruhan produk pengembangan pembelajaran daring yang dihasilkan sudah baik dan layak untuk digunakan. Kemudian ahli media dan bahasa memberikan saran perbaikan yaitu pada gambar dan tulisan yang ada pada produk pengembangan untuk dibuat lebih menarik dan berwana lagi. Berdasarkan angket yang diberikan kepada ahli materi di peroleh skor hasil uji ahli sebagaimana tertuang dalam tabel 1.

Tabel 1. Hasil Uji Ahli Pada Pengembangan Pembelajaran Daring

\begin{tabular}{lccc}
\hline \multicolumn{1}{c}{ Aspek Yang Di Uji } & Skor (\%) & Kriteri & Keterangan \\
\hline Ahli Media dan Bahasa & 87,70 & Layak & Dengan revisi sesuai saran \\
\hline Ahli Materi & 83,68 & Layak & Dengan revisi sesuai saran \\
\hline Uji Validasi Guru SD & 85,66 & Layak & \\
\hline
\end{tabular}


4228 Pengembangan Pembelajaran Daring Materi Bangun Ruang Sederhana menggunakan Metode Pembelajaran Berbasis Proyek dengan Kearifan Lokal Kota Tomohon - Yeremia Gabriel Langi, Jamalri Payow, Gideon Christian, Realita Meydena Andhela Totoda, Juliana Margareta Sumilat

DOI: https://doi.org/10.31004/edukatif.v3i6.1412

Data tabel 1 menunjukan bahwa hasil uji ahli materi, media dan bahasa serta uji validasi guru SD menyatakan pengemabangan produk penbelajaran daring tersebut layak untuk digunakan. Setelah dinyatakan layak digunakan oleh ahli materi, media dan bahasa, maka peneliti melanjutkan penelitian ke tahap uji coba terbatas pada 6 orang peserta didik yang ada di kelas V SD Negeri 2 Tomohon.

Pada uji coba produk, kemampuan peserta didik yang diukur dari 3 ranah hasil belajar yaitu; ranah kognitif, psikomotor dan afektif. Penilaian kognitif peserta didik dilakukan peneliti menggunakan LKPD sebagai lembar evaluasi proses belajar dan Lembar tes akhir sebagai evaluasi akhir. Penilaian proses belajar di hitung dari nilai pesrta didik pada setiap LKPD yang diberikan oleh peneliti melalui google classroom. Nilai setiap peserta didik dari keenam LKPD yang dibagikan tersebut dapat dilihat pada tabel 2 dibawah ini.

Tabel 2. Nilai Proses Pembelajaran peserta didik

\begin{tabular}{|c|c|c|c|c|c|c|c|c|}
\hline \multirow[t]{2}{*}{ No } & \multirow[t]{2}{*}{ Nama Peserta Didik } & \multicolumn{6}{|c|}{ LKPD } & \multirow{2}{*}{$\begin{array}{l}\text { Nilai Rata- } \\
\text { Rata }\end{array}$} \\
\hline & & 1 & II & III & IV & $\mathrm{V}$ & VI & \\
\hline 1 & Prayer Mait & 80 & 85 & 80 & 100 & 85 & 100 & 88,3 \\
\hline 2 & Faith Sumangkut & 80 & 65 & 40 & 100 & 50 & 35 & 61,6 \\
\hline 3 & Adeliya Permata & 100 & 85 & 85 & 100 & 60 & 85 & 85,8 \\
\hline 4 & Manesa Kusumah & 85 & 100 & 70 & 100 & 65 & 80 & 83,3 \\
\hline 5 & Oktasya Kamaludin & 40 & 70 & 100 & 100 & 0 & 15 & 54,2 \\
\hline 6 & Zulkifli Ali & 80 & 100 & 85 & 100 & 80 & 100 & 90,8 \\
\hline
\end{tabular}

Data pada tabel 2 menunjukan bahwa 4 dari 6 peserta didik mendapatkan nilai rata-rata di atas 80-90 dan 2 dari 6 peserta didik tersebut mendapat nilai rata-rata 50-60. Dapat disimpulkan bahwa Sebagian besar peserta didik memiliki nilai proses pembelajaran yang sangat baik pada nilai kognitif. Setelah dilakukan penilaian pada proses pembelajaran peserta didik, selanjutnya peneliti melakukan evaluasi akhir terhadap pembelajaran yang sudah dilakukan dengan menggunakan lembar evaluasi tes akhir yang berisi 3 soal mengenai materi kubus, balok dan prisma tegak segitiga yang sudah diajarkan sebelumnya. Nilai yang diperoleh peserta didik dari tes akhir tersebut dapat dilihat pada tabel 3 dibawah ini.

Tabel 3. Nilai Tes Evaluasi Akhir Peserta Didik

\begin{tabular}{clc}
\hline No & Nama Peserta Didik & Nilai Akhir \\
\hline 1 & Prayer Mait & 100 \\
\hline 2 & Faith Sumangkut & 100 \\
\hline 3 & Adeliya Permata & 100 \\
\hline 4 & Manesa Kusumah & 100 \\
\hline 5 & Oktasya Kamaludin & 86 \\
\hline 6 & Zulkifli Ali & 86 \\
\hline
\end{tabular}

Berdasarkan nilai yang ditunjukan pada tabel 3, 4 nilai tes evaluasi akhir belajar peserta didik menunjukan bahwa 4 dari 6 peserta didik mendapatkan nilai yang sempurna yaitu 100, dan dan 2 dari 6 peserta didik tersebut mendapatkan nilai 86. Dapat disimpulkan bahwa hasil belajar siswa meningkat pada penilaian tes evaluasi akhir. Dan untuk mendapatkan nilai akhir dari setiap peserta didik diambil dari nilai evaluasi proses belajar dan evaluasi akhir belajar peserta didik yang kemudian dijumlahkan sehingga peserta didik memperoleh nilai akhir seperti pada tabel 4 dibawah ini. 
4229 Pengembangan Pembelajaran Daring Materi Bangun Ruang Sederhana menggunakan Metode Pembelajaran Berbasis Proyek dengan Kearifan Lokal Kota Tomohon - Yeremia Gabriel Langi, Jamalri Payow, Gideon Christian, Realita Meydena Andhela Totoda, Juliana Margareta Sumilat

DOI: https://doi.org/10.31004/edukatif.v3i6.1412

Tabel 4. Hasil Belajar Kognitif Peserta Didik Pada Materi Bangun Ruang Sederhana

\begin{tabular}{llcccc}
\hline No & Nama Peserta Didik & $\begin{array}{c}\text { Nilai Proses } \\
\text { Belajar }\end{array}$ & $\begin{array}{c}\text { Nilai } \\
\text { Hasil } \\
\text { Belajar }\end{array}$ & $\begin{array}{c}\text { Nilai Akhir = N.P } \\
(60 \%)+\text { N.H } \\
(40 \%)\end{array}$ & $\begin{array}{c}\text { Predik } \\
\text { at }\end{array}$ \\
\hline 1 & Prayer Mait & 83,3 & 100 & 89,98 & A \\
\hline 2 & Zulkifli Ali & 90,8 & 86 & 88,88 & A \\
\hline 3 & Faith Sumangkut & 61,8 & 100 & 77,08 & B \\
\hline 4 & Adeliya Permata & 85,8 & 100 & 91,48 & A \\
\hline 5 & Oktasya Kamaludin & 54,2 & 86 & 66,92 & B \\
\hline 6 & Manesa Kusumah & 83,3 & 100 & 89,98 & A \\
\hline
\end{tabular}

Keterangan

$\begin{array}{ll}81-100 & : \text { A (Sangat Baik) } \\ 61-80 & : \text { B (Baik) } \\ 41-60 & : \text { C (Cukup) } \\ 21-40 & \text { : D (Kurang) } \\ 1-20 & : \text { E (Sangat Kurang) }\end{array}$

Penilaian Psikomotor peserta didik dilihat berdasarkan hasil kerja proyek yang dikirmkan pada google classroom. Hasil kerja proyek peserta didik dibuat dalam 1 video yang berisi proses dan hasil pembuatan pot bunga bentuk bangun ruang seperti kubus, balok dan prisma tegak segitiga yang dikreasikan menjadi taman mini dirumah masing-masing peserta didik. Juga penilaian pada saat peserta didik menjelaskan atau presentasikan hasil kerja proyek mereka pada saat melakukan kegiatan pembelajaran daring, tatap muka lewat zoom metting. Hasil penilaian tersebut dapat dilihat pada tabel 5 dibawah ini.

Tabel 5. Hasil Belajar Kognitif Peserta Didik Pada Materi Bangun Ruang Sederhana

\begin{tabular}{clcccccc}
\hline \multirow{2}{*}{ No. } & \multirow{2}{*}{ Nama Peserta Didik } & \multicolumn{4}{c}{ Aspek yang dinilai } & \multirow{2}{*}{ Total } & Total Nilai \\
\cline { 3 - 6 } & & A & B & C & D & Skor & \\
\hline 1 & Prayer Mait & 4 & 3 & 4 & 4 & 15 & 93,75 \\
\hline 2 & Zulkifli Ali & 1 & 3 & 3 & 3 & 10 & 62,5 \\
\hline 3 & Faith Sumangkut & 3 & 4 & 4 & 4 & 15 & 93,75 \\
\hline 4 & Adeliya Permata & 3 & 4 & 4 & 3 & 14 & 87,5 \\
\hline 5 & Oktasya Kamaludin & 3 & 3 & 4 & 4 & 14 & 87,5 \\
\hline 6 & Manesa Kusumah & 4 & 3 & 3 & 4 & 14 & 87,5 \\
\hline
\end{tabular}

Keterangan

A : Keterampilan Mempresentasikan hasil kerja proyek

B : Keterampilan Membandingkan volume dua bangun ruang yang berbeda

C : Keterampilan Menyusun bangun ruang

D : Keterampilan berpikir kreatif membentuk pot bunga berbentuk kombinasi bangun ruang kubus, balok dan prisma segitiga

Kurang $=1 \quad$ Cukup $=2 \quad$ Baik $=3 \quad$ Sangat Baik $=4$

Skor Maksimal :16

Total nilai $=\frac{\text { Total Scor }}{\text { Skor Maksimal }} \times 100$

Berdasarkan nilai yang ditunjukan pada tabel 5, dapat disimpulkan bahwa 5 dari 6 peserta didik berhasil membuat proyek yang unik, kreatif dan menarik serta peserta didik dapat menjelaskan proses atau tahapan pembuatan proyek mereka dengan baik. Sementara 1 dari 6 peserta didik tersebut berhasil membuat proyek 
4230 Pengembangan Pembelajaran Daring Materi Bangun Ruang Sederhana menggunakan Metode Pembelajaran Berbasis Proyek dengan Kearifan Lokal Kota Tomohon - Yeremia Gabriel Langi, Jamalri Payow, Gideon Christian, Realita Meydena Andhela Totoda, Juliana Margareta Sumilat

DOI: https://doi.org/10.31004/edukatif.v3i6.1412

tapi masih belum terlalu menarik dan belum bisa menjelaskan proses atau tahapan pembuatan proyek dengan baik.

Penilaian afektif peserta didik dilakukan berdasarkan hasil observasi dari seluruh aktivitas kegiatan pembelajaran yang dilakukan baik secara synchronous dan asynchronous. Penilaian afektif dilihat dari 3 aspek yaitu 1) tanggung jawab peserta didik dalam mengerjakan tugas LKPD ataupun dalam pembuatan proyek, dan 2) kedisiplinan peserta didik pada saat melakukan pembelajaran, serta 3) rasa percaya diri peserta didik pada saat memprsentasikan hasil kerja proyek yang sudah diselesaikan. Hasil penilaian tersebut dapat dilihat pada tabel 6 dibawah ini.

Tabel 6. Hasil Belajar Afektif Peserta Didik Pada Materi Bangun Ruang Sederhana

\begin{tabular}{clccc}
\hline No & Nama Peserta Didik & Tanggung Jawab & Disiplin & Percaya Diri \\
\hline 1 & Faith Sumangkut & 4 & 4 & 4 \\
\hline 2 & Prayer Mait & 4 & 3 & 4 \\
\hline 3 & Manesa Kusumah & 3 & 3 & 4 \\
\hline 4 & Adeliya Permata & 3 & 4 & 3 \\
\hline 5 & Oktasya Kamaludin & 2 & 2 & 4 \\
\hline 6 & Zulkifli Ali & 2 & 2 & 2 \\
\hline
\end{tabular}

Keterangan

Kurang $=1 \quad$ Cukup $=2 \quad$ Baik $=3 \quad$ Sangat Baik $=4$

Berdasarkan nilai yang ditunjukan pada tabel 6, dapat disimpulkan bahwa 1 dari 6 peserta didik memiliki tanggung jawab, kedisiplinan dan rasa percaya diri yang sangat tinggi. 1 dari 6 peserta didik memiliki tanggung jawab, serta rasa percaya diri yang sangat baik dan kedisiplinan yang baik. 1 dari 6 peserta didik memiliki tanggung jawab, serta kedisiplinan yang baik dan rasa percaya diri yang sangat baik.1 dari 6 peserta didik memiliki tanggung jawab, serta percaya diri yang cukup, dan kedisiplinan yang sangat baik. 1 dari 6 peserta didik memiliki tanggung jawab, serta kedisiplinan yang cukup dan rasa percaya diri yang sangat tinggi. 1 dari 6 peserta didik memiliki tanggung jawab, kedisiplinan dan rasa percaya diri yang cukup.

Seluruh kegiatan pembelajaran dan penelitian yang dilakukan oleh peneliti dilakukan secara daring dengan tetap mematuhi prokes yang berlaku. Kegiatan penelitian dan pembelajaran bahkan uji ahli serta uji pada kelompok kesil peserta didik kelas V SD Negeri 2 tomohon dilakukan peneliti dengan cara memanfaatkan perkembangan IPTEK yang ada, Karena adanya wabah covid-19 menuntut lembaga Pendidikan terlebih khusus guru melakukan inovasi dalam proses pembelajaran. Guru professional dituntut untuk memiliki 4 kompetensi dalam menujang inovasi tersebut (Risdiany \& Herlambang, 2021). Salah satu inovasi tersebut adalah dengan melakukan pembelajaran secara daring (Jamaluddin, Ratnasih, Gunawan, \& Paujiah, 2020).

Para peserta didik dapat berinteraksi menggunakan beberapa aplikasi seperti google classroom dan zoom meeting. Pembelajaran yang seperti ini merupakan suatu inovasi untuk menjawab tantangan akan ketersediaan sumber belajar yang variatif di tengah pandemi covid-19 (Bahar, 2020). Pembelajaran daring memiliki fleksibilitsas dalam pelaksanaannya dan mampu mendorong munculnya kemandirian belajar, keberanian mengemukakan gagasan serta meningkatkan motivasi untuk lebih aktif dalam belajar merupakan keuntungan tersendiri dari pembelajaran daring. Namun lemahnya pengawasan dari orang tua terhadap kegiatan pembelajaran peserta didik, menjadi tantangan tersendiri dalam penyelenggaraan pembelajaran daring (Sadikin \& Hamidah, 2020), seperti yang terlihat pada proses pembelajaran daring (uji coba terbatas) terdapat 1 siswa yang tidak menyelesaiakan presentasi hasil kerja proyek taman mini melalui video, karena kesibukan orang tua sehingga minimnya pendampingan orang tua. Temuan penelitian ini juga senanada 
4231 Pengembangan Pembelajaran Daring Materi Bangun Ruang Sederhana menggunakan Metode Pembelajaran Berbasis Proyek dengan Kearifan Lokal Kota Tomohon - Yeremia Gabriel Langi, Jamalri Payow, Gideon Christian, Realita Meydena Andhela Totoda, Juliana Margareta Sumilat

DOI: https://doi.org/10.31004/edukatif.v3i6.1412

dengan temuan penelitian (Harahap et al., 2021) yang menyatakan bahwa dengan adanya perhatian orang tua maka kemandirian belajar dari peserta didik akan meningkat. Kemandirian belajar ini merupakan salah satu unsur penunjang sifat disiplin dan tanggung jawab.

Dalam pelaksanaan pembelajaran daring diperlukan metode yang tepat agar tetap bisa meningkatkan kemampuan peserta didik walau di tengah keadaan pandemi covid-19 sekarang ini. Metode pembelajaran berbasis proyek memiliki pengaruh yang positif terhadap kreatifitas dan hasil belajar peserta didik (Susilowati et al., 2013). Sementara hasil penelitian (Hayati, Supardi, \& Miswadi, 2013) menyatakan model kontekstual berbasis proyek yang dikembangkan mampu memenuhi indikator pembelajaran yang diharapkan, dan mampu membuat peningkatan pada hasil belajar kognitif, afektif dan psikomotor dari peserta didik. Sama halnya dengan pengembanagan pembelajaran daring ini juga menggunakan penilaian hasil belajar pada ketiga ranah tersebut. Selanjutnya (Seke et al., 2018) menyatakan bahwa metode pembelajaran berbasis proyek dapat digunakan sebagai upaya untuk meningkatkan hasil belajar siswa dan kreativitas siswa.

Media pembelajaran merupakan alat bantu guru menyampaikan pesan pembelajaran kepada peserta didik sehingga tujuan pembelajaran dapat tercapai dengan efektif serta efisien (Nurrita, 2018). Salah satunya media pembelajaran audio visual atau video. Pada penelitian ini peneliti menggunakan 2 buah video sebagai media untuk peserta didik melakukan kegiatan pembelajaran dirumah. Menurut penelitian dari (Novita, Sukmanasa, \& Pratama, 2019) kegiatan pembelajaran dengan menggunakan media audio visual atau video memiliki pengaruh positif terlihat dari hasil belajar peserta didik.

Pengembangan LKPD disusun berdasarkan hasil analisis kurikulum serta analisis karakteristik peserta didik kelas V SD Negeri 2 Tomohon. Analisis karakteristik peserta didik perlu dalam pengembangan LKPD karena memberikan gambaran jelas pada peneliti untuk menentukan materi dan gambar yang membuat pencapaian tujuan pembelajaran. Dalam LKPD terdapat aktivitas atau kegiatan yang dilakukan oleh peserta didik baik dalam kegiatan pembelajaran maunpun kegiatan pembuatan proyek, yang dimaksudkan untuk menstimulasi perkembangan anak, seperti hasil penelitian (Anggreani. C, 2021) yang menyatakan bahwa pengembangan LKPD anak berbasis budaya Kalimantan Selatan dapat menstimulasi aspek perkembangan anak.

Pembelajaran daring yang dikembangkan menggunakan dua bentuk yaitu pembelajaran Synchrounous dan asynchronous. Kolaborasi dua bentuk pembelajaran ini lebih dikenal dengan sebutan pembelajaran blended learning dimana merupakan proses pembelajaran yang menggabungkan tatap muka dan online (Kurniawati, Santanapurba, \& Kusumawati, 2019), atau yang menggabungkan pembelajaran langsung secara online dan pembelajaran mandiri. Pembelajaran blended learning menggunakan metode berbasis proyek ini dapat menambah kreatifitas peserta didik dan meningkatkan keefektifan pembelajaran dari jarak jauh (Siregar \& Manurung, 2020), serta menambah pengetahuan peserta didik karena membuat peserta didik belajar secara mandiri (Hidayat, Junaidi, \& Yakob, 2020) dan mendorong penguasaan materi yang lebih baik yang berdampak pada peningkatan hasil belajar peserta didik itu sendiri (Kantun, S., 2015).

Berdasarkan uraian hasil penelitian dan pembahasan diatas maka dapat dinayatakan bahwa pengembangan pembelajaran daring ini dapat meningkatkan kreatifitas, kemadirian belajar, dan kemampuan berkomunikasi serta penguasan materi pembelajaran yang bersinergi pada peningkatan hasil belajar peserta didik itu sendiri.

\section{KESIMPULAN}

Pengembangan produk pembelajaran daring materi bangun ruang sederhana yang dikembangkan dalam penelitian ini telah memenuhi kriteria valid dan layak digunakan. Pengembangan pembelajaran daring materi bangun ruang sederhana ini dapat meningkatkan kreatifitas, kemadirian belajar, dan kemampuan 
4232 Pengembangan Pembelajaran Daring Materi Bangun Ruang Sederhana menggunakan Metode Pembelajaran Berbasis Proyek dengan Kearifan Lokal Kota Tomohon - Yeremia Gabriel Langi, Jamalri Payow, Gideon Christian, Realita Meydena Andhela Totoda, Juliana Margareta Sumilat

DOI: https://doi.org/10.31004/edukatif.v3i6.1412

berkomunikasi serta penguasan materi pembelajaran yang bersinergi pada peningkatan hasil belajar 6 peserta didik kelas V SD Negeri 2 Tomohon. Hasil penelitian pengembangan pembelajaran daring materi bangun ruang sederhana menggunakan metode pembelajaran berbasis proyek dengan kearifan lokal kota tomohon dapat digunakan sebagai solusi pembelajaran daring dimasa pandemi.

\section{UCAPAN TERIMA KASIH}

Terima kasih kepada Kementerian Pendidikan, Kebudayaan, Riset dan Teknologi Direktorat Pembelajaran dan Mahasiswa yang telah mendanai penelitian ini. Terima kasih pula kepada Rektor Unima Prof. Dr. Deitje A. Katuuk, M.Pd dan Pembantu Rektor III Drs. Jim Ronny Tuna, M.AP yang telah mensuport kegiatan penelitian ini. Terima kasih untuk Dr. Agnes M. Goni, M.Pd, Kartini Ester, S.Pd., M.Pd, yang sudah bersedia dan memberikan penilaian sebagai ahli materi. Terima kasih untuk Dr Mersty Rindengan, M.Pd, Dr. Widdy Rorimpandey, S.TP,. M.Pd, Deddy Kumolontang, S.Pd., M.Pd yang sudah bersedia dan memberikan penilaian sebagai ahli bahasa dan media pembelajaran. Terima kasih pula pada kepala sekolah, guru-guru kelas V dan seluruh siswa SD Negeri 2 Tomohon yang sudah membantu pelaksanaan penelitian ini. Serta terima kasih kepada berbagai pihak yang sudah membantu TIM sehingga boleh menyelesaiakan penelitian dan penulisan artikel ini. Semoga hasil penelitian ini dapat memberikan manfaat bagi kemajuan dunia Pendidikan umumnya dan secara khusus pembelajaran di sekolah dasar.

\section{DAFTAR PUSTAKA}

Ameli, Et Al. (2020). Peningkatan Efektivitas Pada Proses Pembelajaran. Mathedunesa, 2(1).

Ananda, R. (2017). Peningkatan Hasil Belajar Siswa Pada Materi Operasi Pengurangan Bilangan Cacah Dengan Menggunakan Blok Dienes Siswa Kelas I SDN 016 Bangkinang Kota. Jurnal Cendekia: Jurnal Pendidikan Matematika, 1(1), 11.

Ananda, R., Fadhilaturrahmi, F., \& Hanafi, I. (2021). Dampak Pandemi Covid-19 Terhadap Pembelajaran Tematik Di Sekolah Dasar. Jurnal Basicedu, 5(3), 1689-1694.

Anggreani. C. (2021). Edukatif: Jurnal Ilmu Pendidikan Pengembangan Lembar Kerja Peserta Didik ( LKPD ) Bermuatan Budaya Lokal Untuk Anak Usia Dini Chresty Anggreani. 3(6), 3500-3508.

Bahar, S. (2020). Permasalahan-Permasalahan Sekolah Menengah Pertama (SMP) Bunda Dalam Pembelajaran Jarak Jauh Sebagai Dampak Pandemi Covid-19. Alasma: Jurnal Media Informasi Dan Komunikasi Ilmiah, 02(02), 217-230.

Elvi. (2018). 済無No Title No Title No Title. 9(2), 102-110.

Fadhilaturrahmi, F., Ananda, R., \& Yolanda, S. (2021). Persepsi Guru Sekolah Dasar Terhadap Pembelajaran Jarak Jauh Di Masa Pandemi Covid 19. Jurnal Basicedu, 5(3), 1683-1688.

Fredyanan, C. A. (2016). Pengembangan Media Pembelajaran Berbasis Android Pada Mata Pelajaran Teknologi Dasar Otomotif Untuk Kelas X Smk Negeri 3 Buduran - Sidoarjo. Jurnal Pendidikan Teknik Mesin UNESA, 5(02), 250480.

Harahap, H. S., Hrp, N. A., Nasution, I. B., Harahap, A., Harahap, A., \& Harahap, A. (2021). Hubungan Motivasi Berprestasi, Minat Dan Perhatian Orang Tua Terhadap Kemandirian Siswa. Edukatif: Jurnal Ilmu Pendidikan, 3(4), 1133-1143.

Hayati, M. N., Supardi, K. I., \& Miswadi, S. S. (2013). Pengembangan Pembelajaran Ipa Smk Dengan Model Kontekstual Berbasis Proyek. Innovative Journal Of Curriculum And Educational Technology, 2(1). Https://Doi.Org/10.15294/Ijcet.V2i1.1261 
4233 Pengembangan Pembelajaran Daring Materi Bangun Ruang Sederhana menggunakan Metode Pembelajaran Berbasis Proyek dengan Kearifan Lokal Kota Tomohon - Yeremia Gabriel Langi, Jamalri Payow, Gideon Christian, Realita Meydena Andhela Totoda, Juliana Margareta Sumilat

DOI: https://doi.org/10.31004/edukatif.v3i6.1412

Hidayat, M. T., Junaidi, T., \& Yakob, M. (2020). Pengembangan Model Pembelajaran Blended Learning Dalam Meningkatkan Pemahaman Siswa Terhadap Tradisi Lisan Aceh. Jurnal Mimbar Ilmu, 25(3), 401-410.

Holis, M. H. (2020). Rekayasa Guru Dalam Pembelajaran.Pdf (1st Ed.; M. H. Holis, Ed.). Surabaya: CV. Jakad Media Publishing.

Jamaluddin, D., Ratnasih, T., Gunawan, H., \& Paujiah, E. (2020). Pembelajaran Daring Masa Pandemik Covid-19 Pada Calon Guru : Hambatan, Solusi Dan Proyeksi. Karya Tulis Ilmiah UIN Sunan Gunung Djjati Bandung, 1-10.

Kantun, S., \& A. (2015). Модель Электронной Библиотеки Для Поддержки Системы «Blended Learning» В Новосибирском Государственном Университете. Библиосфера, (1), 141-152.

Kowaas. (2017). Efektivitas Pelaksanaan Tomohon International Flower Festival Di Kota Tomohon. Jurnal Eksekutif, 2(2).

Kurniawati, M., Santanapurba, H., \& Kusumawati, E. (2019). Penerapan Blended Learning Menggunakan Model Flipped Classroom Berbantuan Google Classroom Dalam Pembelajaran Matematika Smp. EDUMAT: Jurnal Pendidikan Matematika, 7(1), 8-19. Https://Doi.Org/10.20527/Edumat.V7i1.6827

Mahadiraja, D., \& Syamsuarnis. (2020). Pengembangan Modul Pembelajaran Berbasis Daring Pada Mata Pelajaran Instalasi Penerangan Listrik Kelas XI Teknik Instalasi Tenaga Listrik T.P 2019/2020 Di SMK Negeri 1 Pariaman. Jtev (Jurnal Teknik Elektro Dan Vokasional) , 06(01), 77-82.

Nadziroh. (2017). Judul Naskah Publikasi Jurnal JIKDISKOMVIS.

Novita, L., Sukmanasa, E., \& Pratama, M. Y. (2019). Use Of Video Learning Media On Elementary School Student Learning Outcomes. Indonesian Journal Of Primary Education Penggunaan, 3(2), 64-72.

Nurrita, T. (2018). Kata Kunci : Media Pembelajaran Dan Hasil Belajar Siswa. 03, 171-187.

Prastyowati, A. (2020). Mengenal Karakteristik Virus SARS-Cov-2 Penyebab Penyakit COVID-19 Sebagai Dasar Upaya Untuk Pengembangan Obat Antivirus Dan Vaksin. Biotrends, 11(1), 1-10.

Risdiany, \& Herlambang. (2021). Pengembangan Profesionalisme Guru Dalam Mewujudkan Kualitas Pendidikan. Ta'dib, 14(2), 194-202. Https://Doi.Org/10.31958/Jt.V14i2.205

Sa'adah. (2018). Digital Digital Repository Repository Universitas Universitas Jember Jember Digital Jember Digital Repository Repository Universitas Universitas Jember. 68-74.

Sadikin, A., \& Hamidah, A. (2020). Pembelajaran Daring Di Tengah Wabah Covid-19. Biodik, 6(2), 109-119. Https://Doi.Org/10.22437/Bio.V6i2.9759

Seke, F. R., Sumilat, J. M., Kembuan, D. R. E., Kewas, J. C., Muchtar, H., \& Ibrahim, N. (2018). ProjectBased Learning In Programmable Logic Controller. IOP Conference Series: Materials Science And Engineering, 306(1). Https://Doi.Org/10.1088/1757-899X/306/1/012042

Siregar, N., \& Manurung, S. L. (2020). Pengaruh Blended Learning Terhadap Kreativitas Mahasiswa Calon Guru Di Universitas Negeri Medan. Edumatika: Jurnal Riset Pendidikan Matematika, 3(1), 44. Https://Doi.Org/10.32939/Ejrpm.V3i1.485

Susilowati, I., Retno Sri Iswari, \& Sukaesih, S. (2013). Pengaruh Pembelajaran Berbasis Proyek Terhadap Hasil Belajar Siswa Materi Sistem Pencernaan Manusia. Journal Of Biology Education, 2(1). Https://Doi.Org/10.15294/Jbe.V2i1.2618 